Metallophysics and Advanced Technologies

Металофіз. новітні технол.

Metallofiz. Noveishie Tekhnol.

2021, vol. 43, No. 9, pp. 1175-1193

https://doi.org/10.15407/mfint.43.09.1175

Reprints available directly from the publisher
(C) 2021 G. V. Kurdyumov Institute for Metal Physics, National Academy of Sciences of Ukraine Published by license under

the G. V. Kurdyumov Institute for Metal PhysicsN.A.S. of Ukraine Publishers imprint. Printed in Ukraine.

PACS numbers: 61.05.cp, 61.72.Dd, 64.70.D-, 68.37.Hk, 68.70.+w, 81.20.Vj

\title{
Features of the Microstructure of Welded Joints of Single Crystals of Heat-Resistant Nickel Alloys
}

\author{
K. A. Yushchenko, B. A. Zadery, I. S. Gakh, A. V. Zviagintseva, \\ L. M. Kapitanchuk, I. V. Nesina, and O. P. Karasevska*
}

E.O. Paton Electric Welding Institute, N.A.S. of Ukraine,

11 Kazymyr Malevych Str. UA-03150 Kyiv, Ukraine

"G.V.Kurdyumov Institute for Metal Physics, N.A.S. of Ukraine, 36 Academician Vernadsky Blvd., UA-03142 Kyiv, Ukraine

The peculiarities of the microstructure of welded joints of single crystals of heat-resistant nickel alloys made by electron beam welding are considered. The main structural areas of the welded joint are identified: the base metal, the heat effect zone (HAZ), the fusion area, the epitaxial growth zone, the weld sections corresponding to different deviations of the maximum heat dissipation from the orientation of the predominant crystal growth. The dependences of the structure of separate areas, their sizes from the initial crystallographic orientation of the single crystal, the brand of the studied alloy, temperature-temporal and temperature-spatial parameters of the process, determined mainly by welding modes, are established. HAZ is dominated by changes $\left(\gamma+\gamma^{\prime}\right)$-structures consisting in complete or partial dissolution of the primary $\gamma^{\prime}$-phase, large globular eutectic formations with subsequent (upon cooling) separation of the dispersed nanosized secondary $\gamma^{\prime}$-phase. The weld metal is characterized by more noticeable changes in the dendritic structure-variables in the cross section of the weld, its parameters and morphology, a decrease in chemical inhomogeneity compared to the original metal. Changes in the characteristics of the $\gamma^{\prime}$-phase in the cross section of the weld in comparison with HAZ are less noticeable. It is pointed out despite the posi-

Corresponding author: Hanna Vitaliyivna Zviagintseva

E-mail: zvanna@paton.kiev.ua, azvyagintseva@ukr.net

Citation: K. A. Yushchenko, B. A. Zadery, I. S. Gakh, A. V. Zviagintseva, L. M. Kapitanchuk, I. V. Nesina, and O. P. Karasevska, Features of the Microstructure of Welded Joints of Single Crystals of Heat-Resistant Nickel Alloys, Metallofiz. Noveishie Tekhnol., 43, No. 9: 1175-1193 (2021), DOI: $10.15407 /$ mfint.43.09.1175. 
tive changes in the welding of the single-crystal structure, the need in each case for a comprehensive approach aimed at refining the welding technology and heat treatment from the standpoint of homogeneity and optimization of the weld structure as a whole.

Key words: single crystals of heat-resistant nickel alloys, particle size and morphology of dendrites and $\gamma^{\prime}$-phase, crystallographic orientation, structural zones of welded joints.

Розглянуто особливості мікроструктур зварних з'єднань монокристалів жароміцних нікелевих стопів, виконаних електронно-променевим зварюванням. Виділено основні структурні ділянки зварного з'єднання: основний метал, зона термічного впливу (ЗТВ), ділянка стоплення, зона епітаксійного росту, ділянки шва, які відповідають різному відхиленню максимального тепловідводу від орієнтації переважного росту кристала. Встановлено залежності структури окремих ділянок, їх розмірів від вихідної кристалографічної орієнтації монокристалів, марки досліджуваного стопу, температурно-часових та температурно-просторових параметрів процесу, що визначаються головним чином режимами зварювання. У ЗТВ превалюють зміни $\left(\gamma+\gamma^{\prime}\right)$-структури, що полягають у повному або частковому розчинені первинної $\gamma^{\prime}$-фази, найбільших глобулярних евтектичних утворень з подальшим (при охолодженні) виділенням дисперсної нанорозмірної вторинної $\gamma^{\prime}$-фази. Метал шва характеризується більш помітними змінами дендритної структури - змінними по перетину шва її параметрами та морфологією, зменшенням хемічної неоднорідності порівняно з вихідним металом. Зміни характеристик $\gamma^{\prime}$-фази по перетину шва порівняно із ЗТВ менш помітні. Указано, не дивлячись на позитивні зміни у разі зварювання монокристалічної структури, на необхідність у кожному конкретному випадку комплексного підходу, направленого на доробку технологій зварювання та термічної обробки з позицій однорідності та оптимізації структур кожного з’єднання в цілому.

Ключові слова: монокристали жароміцних нікелевих стопів, розмір частинок та морфологія дендритів та $\gamma^{\prime}$-фази, кристалографічна орієнтація, структурні зони зварних з'єднань.

(Received June 1, 2021)

\section{INTRODUCTION}

Due to a successful combination of unique properties, single crystals of high-temperature nickel alloys are widely used as a structural material for the manufacture of hot-section elements for aircraft and marine gas turbine engines (GTE), industrial gas pumping and power plants, jet engines, and space objects [1-7].

To meet the requirements for the operational characteristics of products in these industries, complex alloying and growing of parts with a single crystal structure is insufficient, and complex designs have to be created. The production of units and parts of complex geom- 
etry by methods of directional crystallization, despite the success of growing single crystals [7-9], is a complex technological problem, not always economically justified, and sometimes fundamentally impossible. Therefore, the task is to manufacture such products from separate, simpler components by welding. First of all, this applies to such details as long blades, cooled rotor blades of GTE with a complex system of internal channels and cavities, developed perforation. Similar tasks also arise when creating joints, the individual elements of which are under the influence of different temperature and power loads. For example, individual parts of a blade, a rotor drum-a blade, a butt-a blade air foil, etc. The issue of repairing products of this kind remains topical.

It is known $[1,3,5,7]$ that the mechanical properties and service characteristics of high-temperature nickel alloys single crystals, in addition to the crystallographic orientation, are largely determined by the following structure parameters:

- volume fraction, dispersion, morphology of the $\gamma^{\prime}$-phase, as well as other strengthening phases-carbides, borides, eutectic formations, their placement in the matrix of the $\gamma$-solid solution;

- size and morphology of dendrites;

- chemical and structural heterogeneity;

- misfit of the periods of the crystal lattices of the $\gamma$ - and $\gamma^{\prime}$-phases;

- physicochemical and mechanical properties of $\gamma$ - and $\gamma^{\prime}$-phases;

- temperature of complete dissolution of the $\gamma^{\prime}$-phase in the $\gamma$-solid solution.

When growing single crystals, an acceptable combination of these characteristics is achieved mainly by controlling the main parameters of directional crystallization, such as the temperature gradient at the solidification front $(G)$ and the crystal growth rate $(R)$ by controlling the heating and cooling process $[1,3,5,7]$.

The currently technically achievable control of these parameters makes it possible to obtain satisfactory values of the main structure and performance properties of high-temperature nickel alloys single crystals. However, if the growth of single crystals takes place under relatively equilibrium conditions, then the formation and crystallization of welds is characterized by extreme nonequilibrium, inhomogeneity of temperature-time, hydrodynamic, thermal-deformation and orientational conditions.

And, if for the industrial growth of single crystals the optimal values of these characteristics, the methods and ways of achieving them have been sufficiently clarified, then for welded joints such data are clearly insufficient, despite the large number of publications, which are mainly devoted to the preservation of the initial crystallographic orientation by the weld metal, the formation of high-angle boundaries, grains and cracks [10-16]. 
Less attention is paid to the characteristics of the structure, which, in addition to the crystallographic orientation, determine the mechanical properties and service characteristics of welded joints.

The purpose of this work is to study the peculiarities of changes in the parameters of the structure of single crystals of high-temperature nickel alloys as a result of the action of thermal deformation cycles of welding, to clarify the possibility of controlling them by technological means. Electron beam welding (EBW) is chosen due to its well-known advantages - it is high specific power, wide possibilities of control of thermo-deformation welding cycles and weld crystallization, reliable protection against negative influence of the atmosphere. Contamination of the weld metal with impurities is dangerous not only by the deterioration of the properties of welded joints, but also by the structural disruption of the single-crystal up to the formation of grains of a different crystallographic orientation and, as a consequence, cracks.

\section{EXPERIMENTAL/THEORETICAL DETAILS}

The investigated materials are industrial alloys such as ZhS26, ZhS32, ZhS36 [1, 7]. Samples with a thickness of $1.5-2.5 \mathrm{~mm}$ for welding are made by oriented cutting by the electric spark method from singlecrystal workpieces with a thickness of $5-8 \mathrm{~mm}$, obtained by the method of high-gradient directional crystallization. Crystallographically oriented specimens is carried out in a vacuum by electron beam welding.

Welding is carried out in modes providing through penetration of the samples with the formation of a root bead and fusion surfaces close to parallel. Since the welding speed under these conditions is the main technological thermoregulatory parameter, it is changed in a wide range of acceptable values from 12 to $120 \mathrm{~m} / \mathrm{h}$ with corresponding changes in the remaining parameters of the regime.

Transverse and longitudinal sections of welded joints are prepared according to a standard technique, the structure is revealed by the method of ion bombardment of the surface of the sections, or using the method of reflected electrons when studying non-etched sections in SEM.

Structural studies are performed using optical (Neophot-32), scanning electron (Camskan-4, SEM-515 PHILIPS with an attachment for EDX analysis) microscopy, X-ray diffractometry (DRON-3M diffractometer with single-crystal $\mathrm{Cu} K_{\beta}$ radiation). Determination of the crystallographic orientation before cutting, assembly for welding, and study of the structure is carried out by analysing the distribution of the intensity of X-ray reflection on the pole figures [17-18]. According to the intensity distribution on the ' $\theta-2 \theta$ ' $\mathrm{X}$-ray diffraction patterns $\left(I_{\mathbf{q}}\right)$ in the direction of the diffraction vector $(\mathbf{q})$ and in the plane perpendicular to it $-I_{\mathbf{q} \perp}$, the crystallographic and dislocation structure 
of individual sections of welded joints is evaluated.

\section{RESULTS}

The following characteristic structural areas of the welded joint are considered (Fig. 1): base metal, heat-affected zone, fusion area, epitaxial weld growth zone, areas corresponding to different deviations of the maximum heat removal along the solidification front of the weld pool from the direction of predominant crystal growth.

\subsection{Base Metal}

Base metal is characterized by a developed homogeneous largedendritic structure, the presence of cuboid particles of the $\gamma^{\prime}$-phase

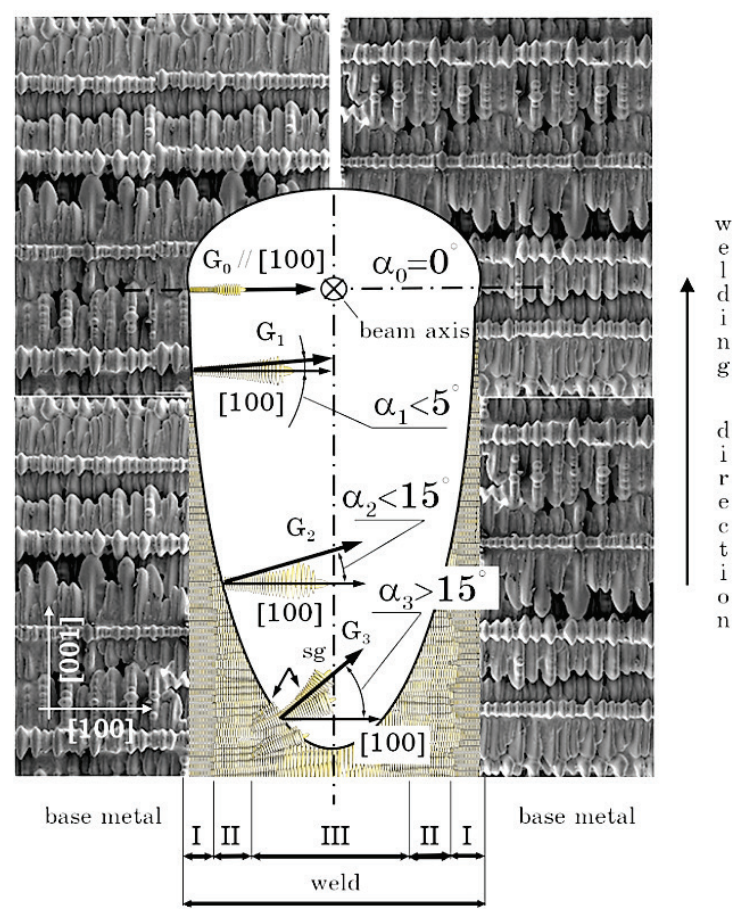

Fig. 1. Schematic representation of the formation of weld metal structural sites during crystallization of a single crystal of heat-resistant nickel alloy. $G$ is the direction of the maximum temperature gradient on the macrofront of the weld pool crystallization; $\alpha$ is the angle between $G$ and the orientation of preferential growth [100]; I is a section of the weld metal of epitaxial growth $\alpha<5^{\circ}$; II is section of weld metal $\alpha<15^{\circ}$; III is section of weld metal $\alpha>15^{\circ}$; $\mathrm{HAZ}$ are stray grains. 

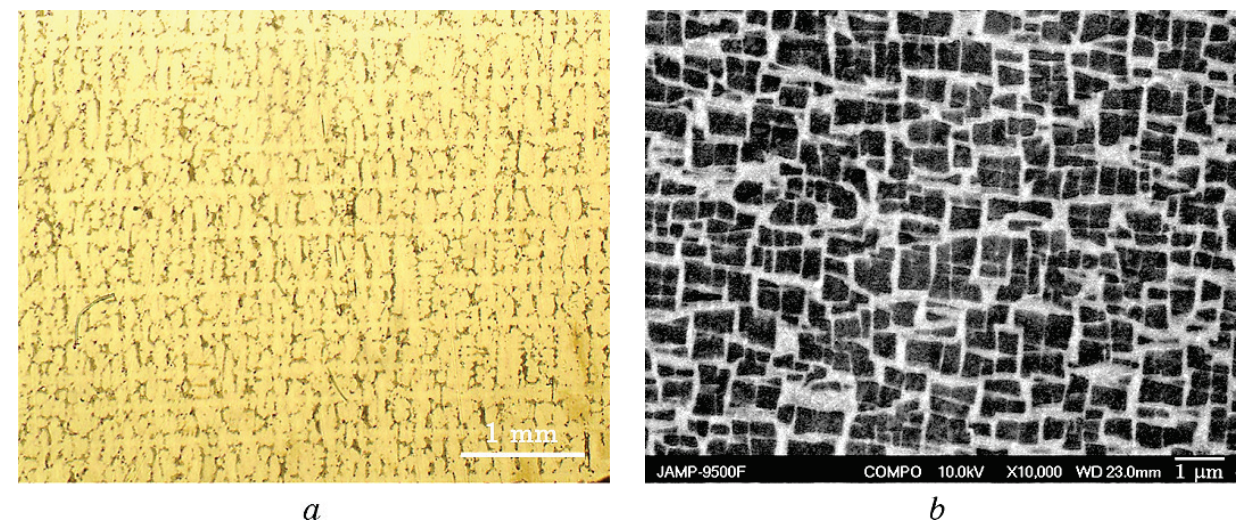

Fig. 2. The base metal structure $(a, b)$ of the ZhS26 alloy.

based on the $\mathrm{Ni}_{3} \mathrm{Al}$ compound, separated by interlayers of $\gamma$-solid solution of nickel (Figs. 1, 2). It is a typical structure for heat-resistant nickel alloys single crystals obtained by high-gradient directional crystallization.

The inter-axial distances $(\lambda)$ of the first order dendrites are 200-300 $\mu \mathrm{m}$, the size of the precipitates $\gamma^{\prime}$-phase is $300-500 \mathrm{~nm}$, the interlayer of the $\gamma$-solid solution $\sim 50-100 \mathrm{~nm}$. The size of $\gamma^{\prime}$-phase particles in the axial section of the dendrite is 3-5 times smaller than in the interdendrite gap and has a slightly different morphology. Separate large globular eutectic $\left(\gamma+\gamma^{\prime}\right)$-formations are observed in the interdendritic gaps and have size $4-8 \mu \mathrm{m}$, up to $30 \mu^{2}$ in area. The metal is characterized by noticeable chemical heterogeneity due to the features of dendritic crystallization of high-alloyed nickel alloys. Tungsten is most noticeably eliminated, followed by molybdenum and chromium, enriching the axial sections of dendrites. Less noticeable is the liquation of titanium, aluminium, niobium, (Table 1). In the carbon-containing alloys ZhS26, $\mathrm{ZhS32}$, in the interdendrite gaps, carbide precipitates of the type $\mathrm{MeC}$, $\mathrm{Me}_{23} \mathrm{C}_{6}, \mathrm{Me}_{6} \mathrm{C}$, rounded with a diameter of up to $2 \mu \mathrm{m}$ and elongated acicular precipitates up to $10 \mu \mathrm{m}$ in length, are observed.

The distribution of the intensity $I_{\mathbf{q} \perp}$ of X-ray reflection (Fig. 6) made

TABLE 1. Values of the distribution coefficients of the main $k_{1}=C_{\text {d. }} / C_{\text {i.d. }}$. chemical components of the initial alloy ZhS26 and weld metal, where $k_{1}$ liquation coefficient, $C_{\mathrm{d}}$ - concentration in the dendrite axis, $C_{\text {i.d. }}-$ concentration in the interdendritic space.

\begin{tabular}{c|c|c|c|c|c|c|c|c}
\hline & $\mathrm{Al}$ & $\mathrm{Ti}$ & $\mathrm{V}$ & $\mathrm{Cr}$ & $\mathrm{Co}$ & $\mathrm{Nb}$ & $\mathrm{Mo}$ & $\mathrm{W}$ \\
\hline Base metal & 0.7 & 0.55 & 1.28 & 1.98 & 1.2 & 0.6 & 1.6 & 1.89 \\
Weld & 0.94 & 0.7 & 1.2 & 1.04 & 1.02 & 0.9 & 1.08 & 1.24 \\
\hline
\end{tabular}


it possible to estimate the parameters of the dislocation ensembles of the considered sections of the welded joints. Symmetric with respect to mutually perpendicular directions with a smooth Gaussian distribution function $I_{\mathbf{q} \perp}$ indicates a disordered uniform distribution of dislocation defects at the macrostructural level in the base metal (Fig. 6, $a$, $e)$ typical of heat-resistant nickel alloys single crystals.

\subsection{Heat Effected Zone (HAZ)}

By HAZ in this study, we mean a section of the metal near the weld, in which there are noticeable changes in precipitates of the main hardening $\gamma^{\prime}$-phase. Due to the high concentration of the power of the electron beam, the high heat transfer coefficient during the specified formation of the weld, the low thermal conductivity of the of heatresistant nickel alloys single crystals, the width of HAZ does not exceed $0.6 \mathrm{~mm}$ with a width of the weld of $\sim 2-3 \mathrm{~mm}$ and significantly depends on the welding speed. In welded joints ZhS26, ZhS32, made at a speed of $12 \mathrm{~m} / \mathrm{h}$, it is $\sim 0.6-0.8 \mathrm{~mm}$, and at $90 \mathrm{~m} / \mathrm{h}$ it is $\sim 0.2-0.3 \mathrm{~mm}$.

In the welded joints of the ZhS36 alloy, it is 2-3 times narrower in comparison with the ZhS26 alloy, which is mainly explained by the higher temperature of dissolution of the $\gamma^{\prime}$-phase.

As one approaches the fusion line, there is a gradual increase in the dissolution of the $\gamma^{\prime}$-phase in the matrix $\gamma$-solid solution (Fig. 3) with a corresponding change in its morphology from exactly cuboid to cuboid with rounded corners, petal-like, and up to complete dissolution.

The degree of dissolution, like the width of the HAZ, is also determined by the chemical composition of the alloy, i.e. the temperature range of dissolution of the $\gamma^{\prime}$-phase, and technologically by the welding speed, i.e. by heating and cooling rate.

At the sites of the dissolved $\gamma^{\prime}$-phase, during cooling, finely dispersed $(\sim 50-100 \mathrm{~nm})$ particles of the $\gamma^{\prime}$-phase and smaller nanosized $(\sim 20-50 \mathrm{~nm})$ particles are released in the areas of the matrix $\gamma$-solid solution. The observed difference is most likely due to the different chemical composition of the matrix $\gamma$-solid solution and composition of the area at the sites of the dissolved primary $\gamma^{\prime}$-phase.

The high degree of dispersion of the precipitated $\gamma^{\prime}$-phase is determined by the cooling rate of the alloy in the temperature range of its formation (dissolution). For the welded joints of the $\mathrm{ZhS} 26$ alloy, it is $\sim 50^{\circ} \mathrm{C} / \mathrm{s}$ at a welding speed of $12 \mathrm{~m} / \mathrm{h}, 320^{\circ} \mathrm{C} / \mathrm{s}$ at $53 \mathrm{~m} / \mathrm{h}, 240^{\circ} \mathrm{C} / \mathrm{s}$ at $90 \mathrm{~m} / \mathrm{h}$, respectively.

Melting of the surface of dendrites and eutectic $\gamma-\gamma^{\prime}$-formations is observed directly near the fusion zone. This is especially noticeable in the welded joints of the ZhS26 alloy, made at low speeds in the areas where the second-order axes output the fusion line (Fig. 4).

Near the fusion zone of welded joints made at a speed of $12 \mathrm{~m} / \mathrm{s}$, the 
size of the $\gamma^{\prime}$-phase precipitates in the place of the primary $\gamma$-solid solution leaves $\sim 50-80 \mathrm{~nm}$, in the place of the primary $\gamma^{\prime}$-phase $\sim 100 \mathrm{~nm}$. For welded joints made at a speed of $53-90 \mathrm{~m} / \mathrm{h}$, the size is reduced to 30-60 $\mathrm{nm}$. Moreover, the difference in the dimensions of the $\gamma^{\prime}$-phase between the seams made at 53 and $90 \mathrm{~m} / \mathrm{h}$ is less distinguishable.

Around large partially dissolved precipitates of the primary $\gamma^{\prime}$ phase, smaller, hardly distinguishable particles of the $\gamma^{\prime}$-phase are observed (Fig. 5, a), which, apparently, is the result of its surface dissolution upon heating or the formation and melting of the eutectic.

Directly at the fusion line at the site of separate larger primary precipitates of the $\gamma^{\prime}$-phase $(\sim 320-350 \mathrm{~nm})$, a chemical heterogeneity is observed (Fig. 3, $c$ and Fig. 5) with the predominance of $\gamma$-forming elements and precipitates of the secondary $\gamma^{\prime}$-phase with a size of $\sim 100-$ $120 \mathrm{~nm}$. Such changes are especially noticeable in welded joints of ZhS36 alloy (Fig. 5).

The features of dislocation HAZ assemblies determine the change in

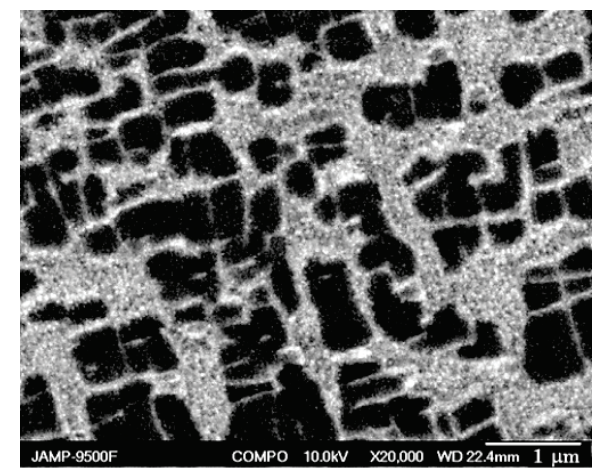

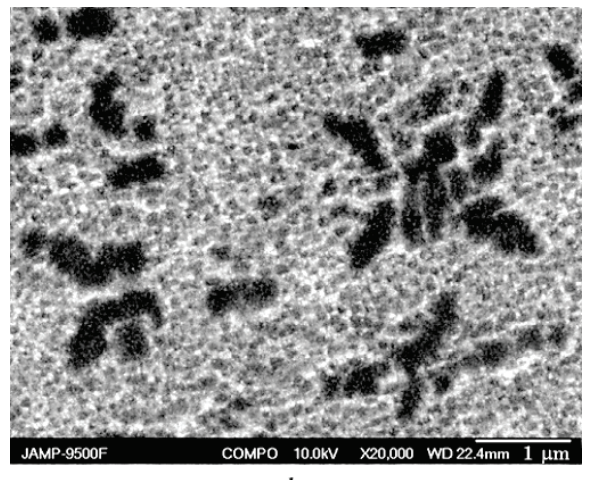

b

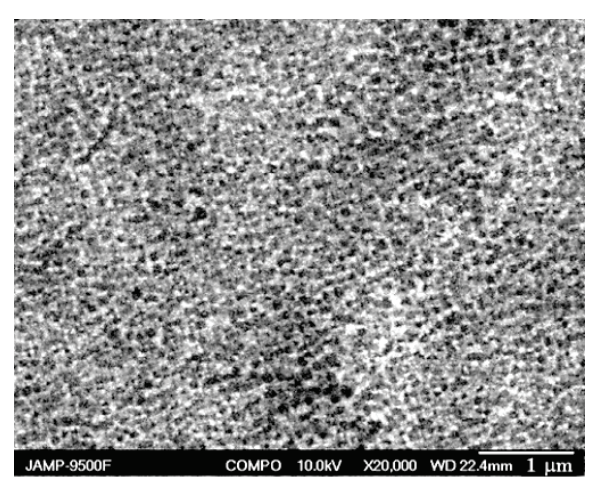

$c$

Fig. 3. The structure of several sections of the heat-affected zone of the welded joint of the ZhS26 alloy with different degrees of dissolution of the $\gamma^{\prime}$-phase. Distance from the fusion line: 593 microns $(a), 369$ microns $(b), 89$ microns $(c)$. 
the initial ellipsoidal shape and size of the $I_{\mathbf{q} \perp}$ distribution (Fig. 6, b). An increase in the width of iso-intensive lines in one direction, tortuosity of the formation contour, the appearance of localized asymmetric regions, an increase in reflection intensity indicate the initial stage of the formation of a multilevel dislocation structure, and an increase in the dislocation density $[14,16]$ as a result of thermos-deformation effect of welding.

\subsection{Fusion Zone}

The fusion zone is characterized by a transitional structure from a partially melted surface of dendrites and interdendrite gaps, incl. eutectic

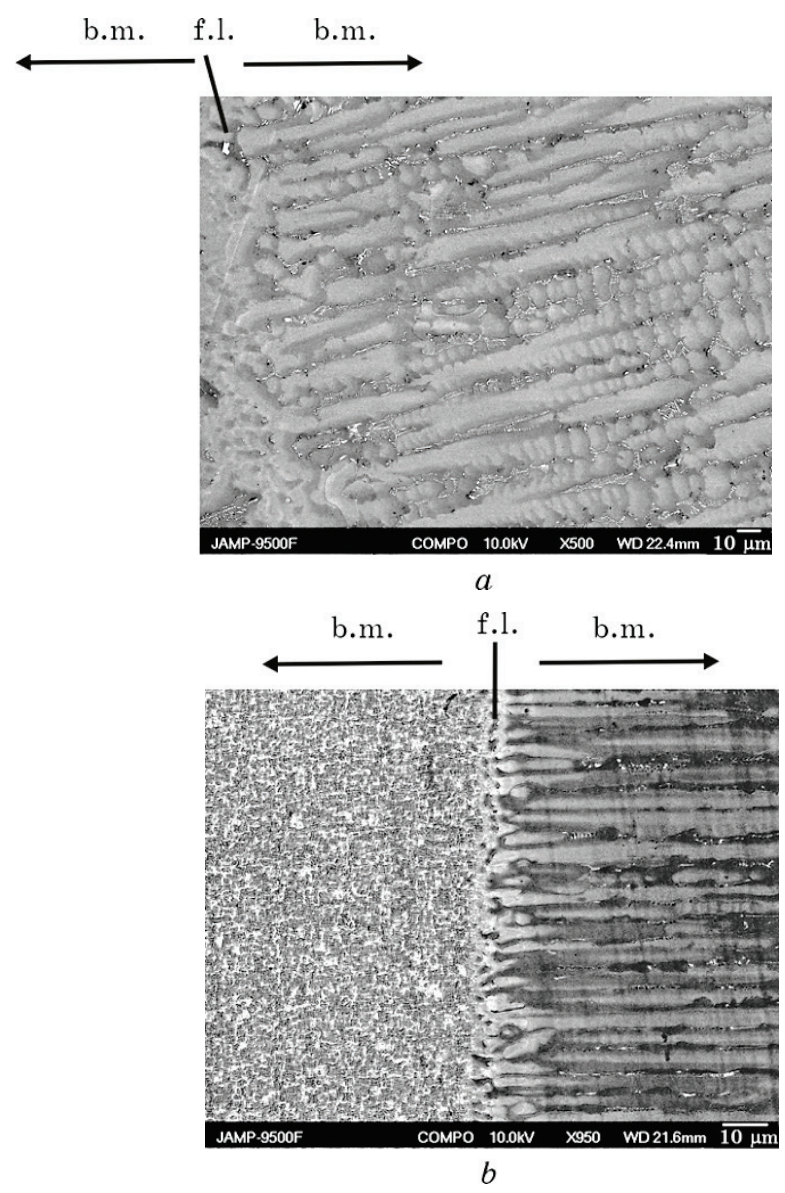

Fig. 4. The structure of the fusion area metal of the welded joints of the ZhS26 alloy, made at a speed of $12 \mathrm{~m} / \mathrm{h}(a)$ and $53 \mathrm{~m} / \mathrm{h}(b)$, b.m.- base metal, f.l.fusion line. 
$\gamma-\gamma^{\prime}$-precipitates, completely dissolved by the primary $\gamma^{\prime}$-phase to the zone of epitaxial growth of the weld metal (Figs. 4 and $7, a$ ). In this case, the crystallographic orientation of the base metal does not change (Fig. 6), partially melted dendrites get the shape of equiaxed cells.

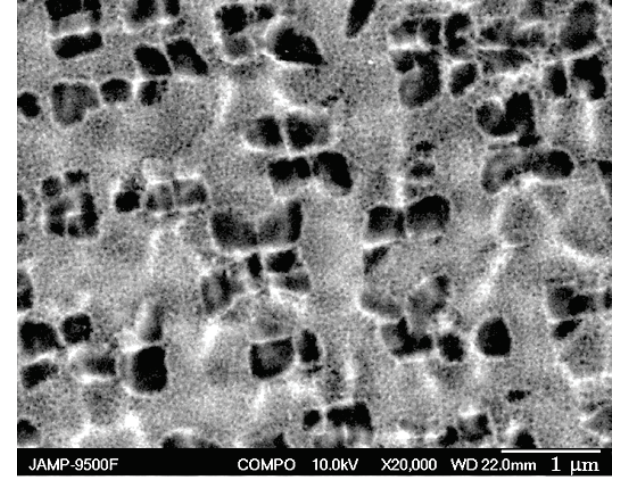

$a$

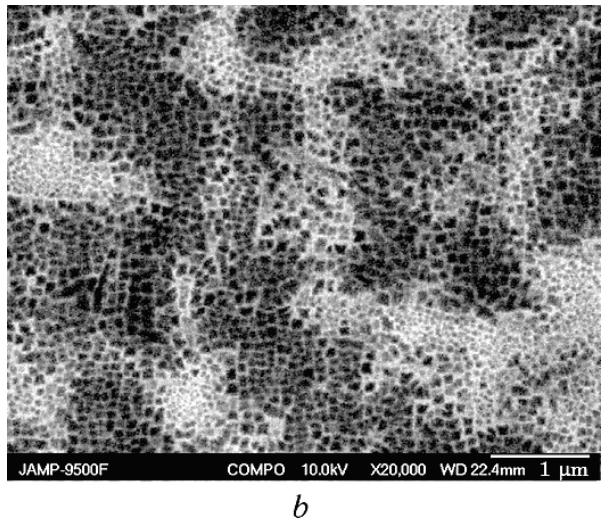

Fig. 5. The structure of HAZ metal of the ZhS36 alloy: partial dissolution of the surface of the $\gamma^{\prime}$-phase $\left(v_{\mathrm{w}}=53 \mathrm{~m} / \mathrm{h}\right)(a)$, chemical inhomogeneity at the place of dissolution of the $\gamma^{\prime}$-phase $\left(v_{\mathrm{w}}=90 \mathrm{~m} / \mathrm{h}\right)(b)$.

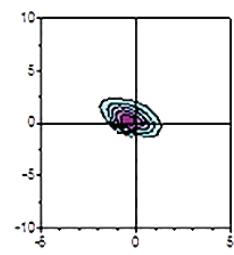

$a$

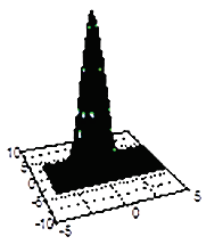

$e$

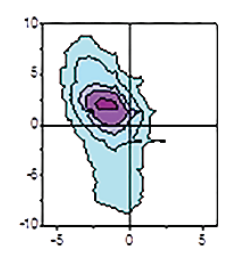

$b$

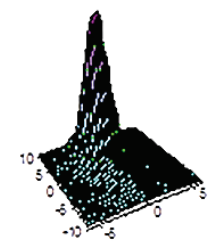

$f$
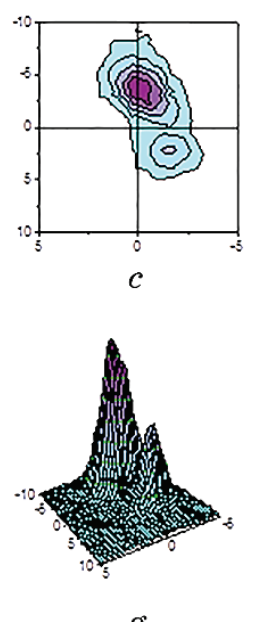

$g$
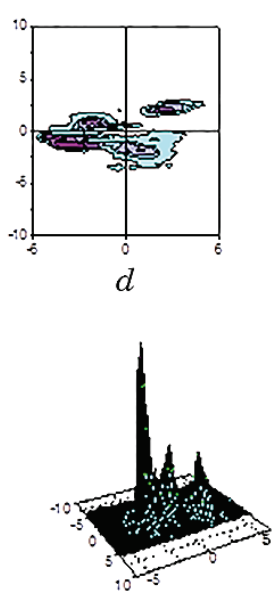

h

Fig. 6. Isointensive $(a, b, c, d)$ and three-dimensional $(e, f, g, h)$ curves of distributions $I_{\mathrm{q} \perp}$ of X-ray reflection $\{220\}$ in the welded joint of ZhS26 alloy with a sequential change in the irradiation region from the base (initial) metal $(a, e)$ through the heat-affected zone $(b, f)$, the section of the weld metal with a deviation of $\alpha \leq 10^{\circ}(c, g)$ to the centre of the weld with a deviation of $\alpha \geq 15^{\circ}(d, h)$. $\alpha$ is the angle between $G$ and the orientation of preferential growth [100]. 


\subsection{Epitaxial Growth Zone}

The epitaxial growth zone (weld section I in Fig. 1) is a fine-dendritic structure orthogonal to the fusion line, the crystallographic orientation of which corresponds to the base metal with minimal distortion of the single-crystal structure (Figs. 6, 7). According to the results of studies by the method of X-ray diffractometry, the misorientation of the structural elements does not exceed 2 degrees. The zone of epitaxial growth is characterized by a significant decrease in the interdendritic distance in comparison with the initial metal, the value of which is largely determined by the welding speed (Fig. 7). So, for the welds of the ZhS26 alloy, made at a speed of $12 \mathrm{~m} / \mathrm{h}$, it is $10-16 \mu \mathrm{m}$, at $90 \mathrm{~m} / \mathrm{h}-5-10 \mu \mathrm{m}$. As the distance from the fusion line increases, the size increases to $20-30 \mu \mathrm{m}$ and $10-15 \mu \mathrm{m}$, respectively, the welding speed, remaining an order of magnitude or smaller than that of the base metal. The change in the size of the precipitates of the hardening

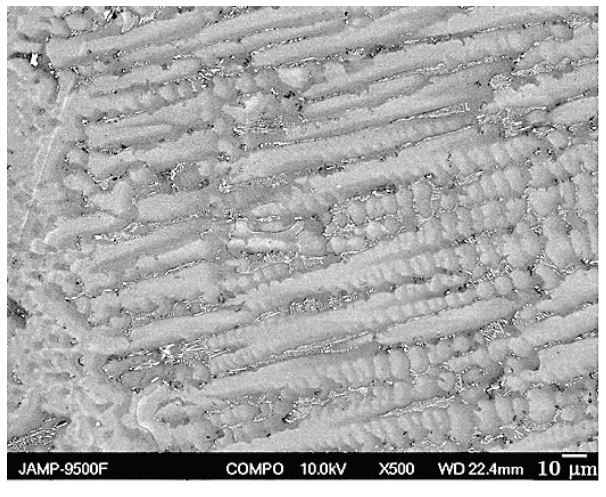

$a$

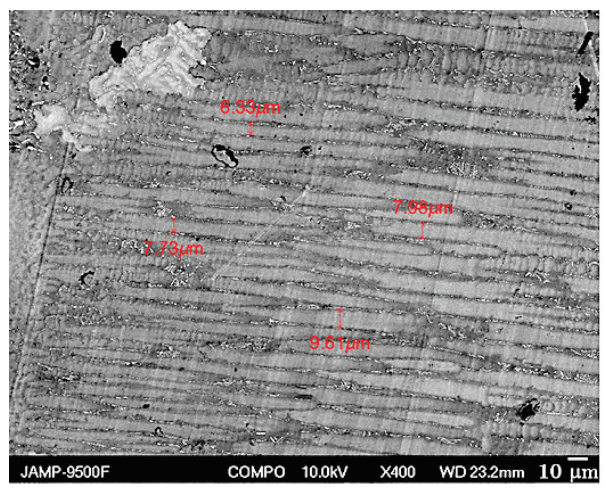

$c$

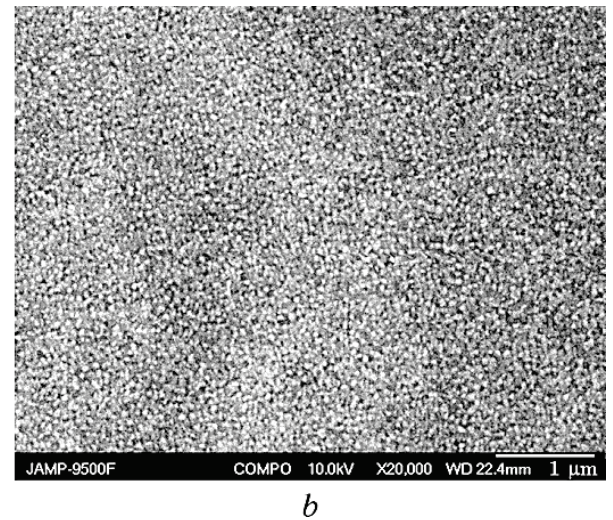

$b$

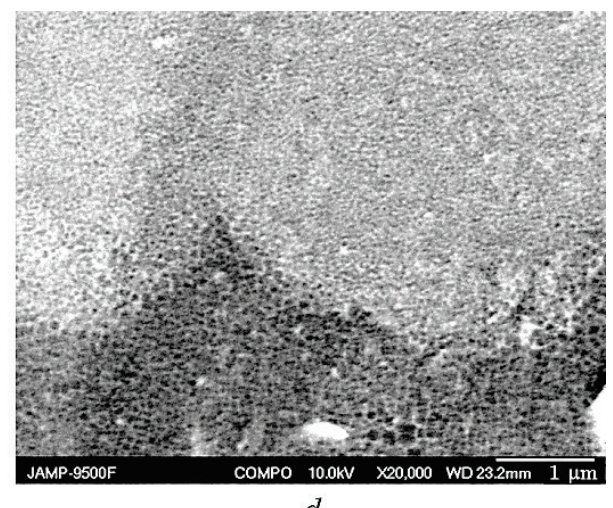

d

Fig. 7. The structure of the zone of epitaxial growth of welds made at speeds: $v_{\mathrm{w}}=12 \mathrm{~m} / \mathrm{h}(a, b), v_{\mathrm{w}}=90 \mathrm{~m} / \mathrm{h}(c, d)$. 
$\gamma^{\prime}$-phase $\left(d_{\gamma^{\prime}}\right)$ is less noticeable. Directly at the fusion line $d_{\gamma^{\prime}}$ is $40-$ $80 \mathrm{~nm}(70-80$-in the interdendrite gaps and $40-50$-in the axes of the dendrites).

The size of the zone, as well as the characteristics of other parameters of the structure, is mainly determined by the degree of correspondence of the flashing surface and the direction of welding with the axes of high symmetry, the curvature of the macrofront of solidification of the weld pool and the temperature-time parameters $G \times R$ (where $G$ is the direction of the maximum temperature gradient on the macrofront of crystallization weld pool, $R$ is the rate of crystallization, $\mathrm{m} / \mathrm{h}$ ) of the process (Fig. 7) [19, 20]. In this case, the zone can reach both the weld axis and decrease to the size of the dendritic cell near the fusion line.

In the epitaxial growth zone and further, as one moves towards the weld axis, the process of the formation of a multilevel dislocation structure intensifies. The fragmentation of the $I_{\mathbf{q} \perp}$ reflection increases up to separation into separate rather smooth regions with the development of expansion in the perpendicular direction with respect to the main direction, the intensity between which significantly decreases (Fig. 6, $c, g$ ).

A significant difference in the width of the $I_{\mathbf{q} \perp}$ distribution in different directions indicates the formation in preferential slip systems of excess and different in magnitude dislocation densities. The inhomogeneity of their distribution determines the fragmentation of $I_{\mathbf{q} \perp}$.

The main feature of the multilevel structure being formed is the presence of subboundaries with a misorientation of 1-2 degrees.

\subsection{Welds Zone}

Welds zone (section II in Fig. 1), corresponding to an increase from 12 to 5-7 degrees of deviation from [001] the direction of maximum heat removal on the front of solidification of the weld pool (Fig. 8).

The structure of the area is characterized by a deviation of the crystallographic orientation from the initial one as it approaches the weld axis up to 10-15 degrees and an increase in the interdendritic distance $\lambda$ to $25-30 \mu \mathrm{m}$. In this case, the effect of the welding speed is appreciable (Fig. 8). So, in the weld made at a welding speed of $12 \mathrm{~m} / \mathrm{h}$, the orientation deviation can reach 15 degrees, an increase of $\lambda$ up to $30 \mu \mathrm{m}$; at $90 \mathrm{~m} / \mathrm{h}-7-10$ degrees and $10-20 \mu \mathrm{m}$, respectively. The misorientation of the substructure exceeds 3 degrees. The observed deviation is mainly associated with an increase in the curvature of solidification of the weld pool and a decrease in the product $G \times R$ as it approaches the weld axis [19].

The change in the $\gamma^{\prime}$-phase parameters within the measurement accuracy is less noticeable and amounts to a few nanometres. 


\subsection{Zone of the Weld Metal}

The zone of the weld metal (weld section III in Fig. 1), corresponding to the deviation of the direction of maximum heat removal from the orientation [001] by 10-15 and more degrees from the front of solidification of the weld pool. During the crystallization of this area, a structural disruption of not only the orientation, but also the temperaturetime conditions $[15,16,19]$ of directional crystallization is observed, which leads to the formation of high-angle grain boundaries, the crystallographic orientation of which may differ from the rest of the weld metal by 35-55 degrees (Fig. 9). The misorientation of the intragranular substructure with an average size of $\sim 6-8 \mu \mathrm{m}$ reaches 2 degrees. The grain size increases to $400-600 \mu \mathrm{m}$ as it approaches the centre line-in places where the maximum value of the weld pool curvature and the minimum $G \times R$ are observed.

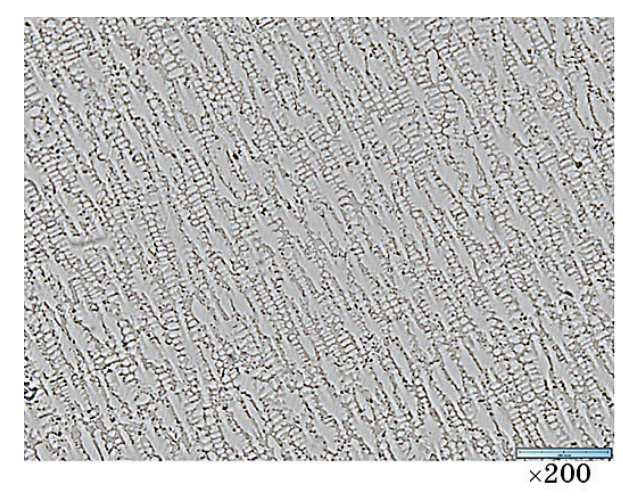

$a$

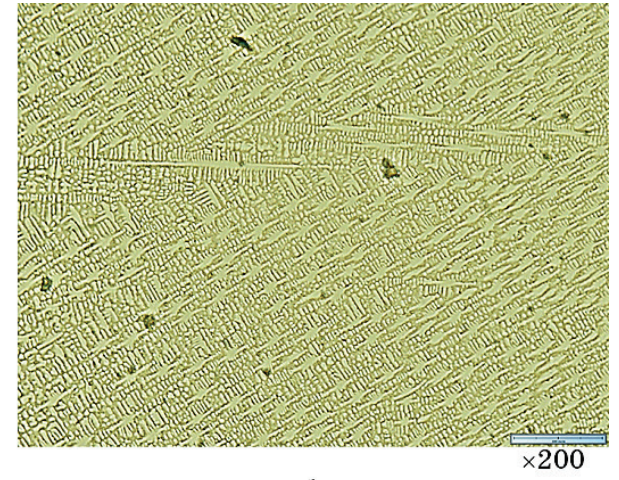

$b$

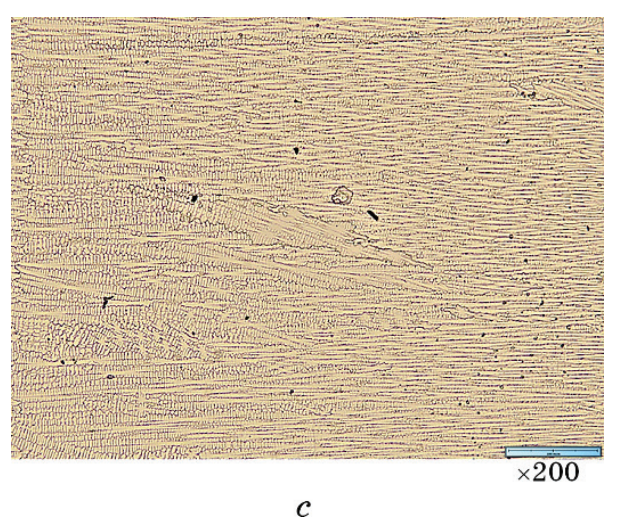

c

Fig. 8. The structure of the sites of the weld metal of the ZhS26 alloy, corresponding to the deviation of the maximum temperature gradient from the [001] direction of $10-15^{\circ}$, made at a speed of $v_{\mathrm{w}}=12 \mathrm{~m} / \mathrm{h}(a), v_{\mathrm{w}}=53 \mathrm{~m} / \mathrm{h}(b)$, $v_{\mathrm{w}}=90 \mathrm{~m} / \mathrm{h}(c)$. 
For the weld sections corresponding to the deviation of the maximum heat removal from the [001] direction $\sim 10-15$ degrees, the $I_{\mathrm{q} \perp}$ distribution, in addition to fragmentation, is divided into separate spots of different intensities, multidirectional, shifted relative to the direction of preferential expansion (Fig. $6, d, h$ ), which is the result of the formation of high-angle grain boundaries (Fig. 9). With an increase in the deviation of the maximum heat removal, the angle between the reflection spots and their intensity increase.

Expansion of the $I_{\mathbf{q} \perp}$ distribution in different directions in separate sections of the welded joint is most likely evidence of local inhomogeneity and predominant orientation of stresses, which, in turn, affects the formation of the substructure.

The crystallographic orientation of the grains, depending on the welding regime and the crystallographic symmetry of the joint, can be

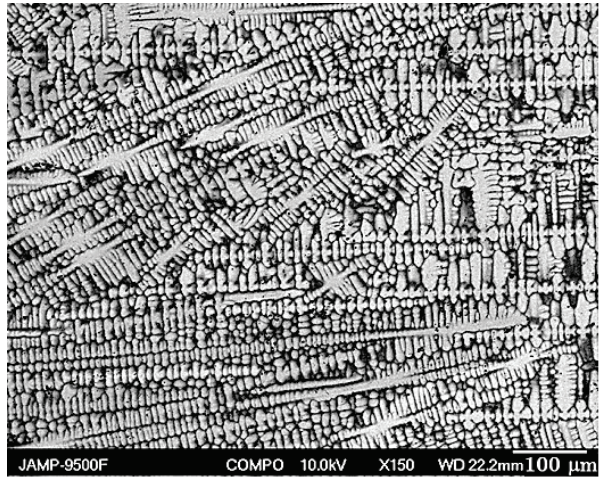

$a$

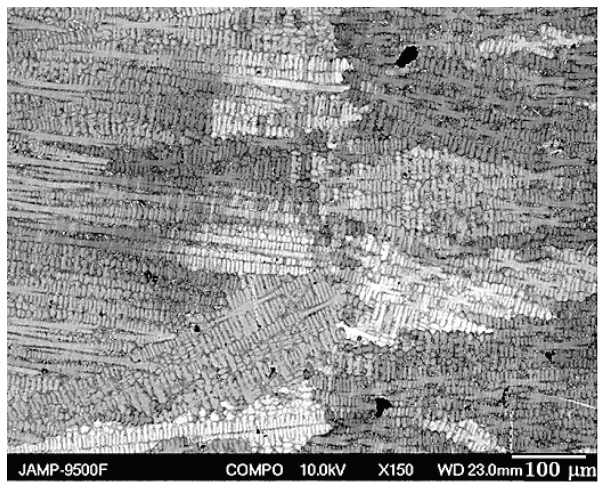

c

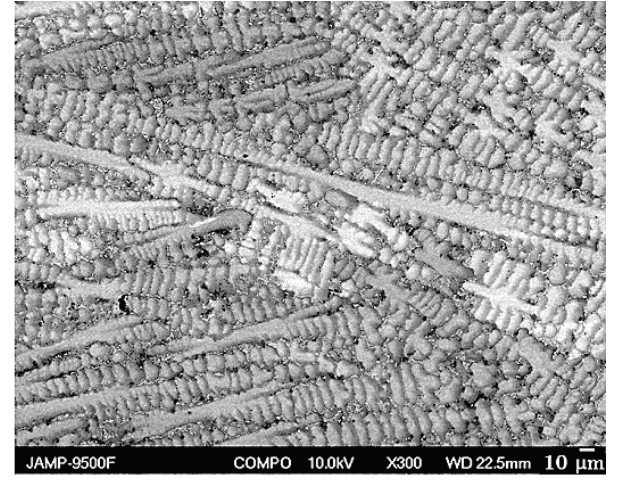

$b$

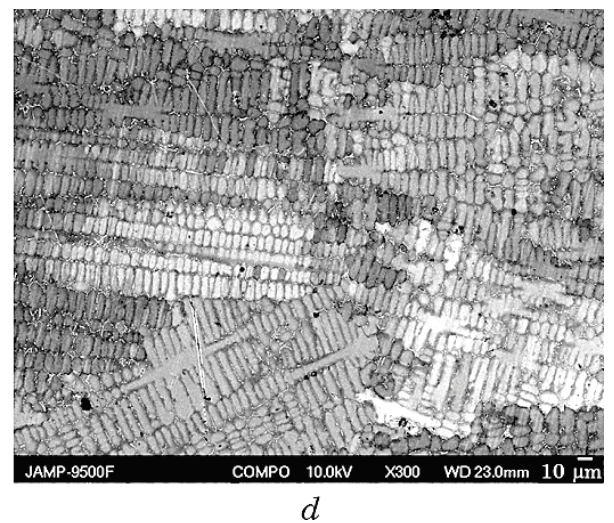

Fig. 9. The structure of the sites of the weld metal of the ZhS26 alloy, corresponding to the deviation of the maximum temperature gradient from the [001] direction of $>15^{\circ}$, made at a speed of $v_{\mathrm{w}}=12 \mathrm{~m} / \mathrm{h}(a), v_{\mathrm{w}}=53 \mathrm{~m} / \mathrm{h}(b)$, $v_{\mathrm{w}}=90 \mathrm{~m} / \mathrm{h}(c)$. 
of the most arbitrary directions, corresponding to points on the area of the entire stereographic triangle, which indicates the nonequilibrium process of crystallization of the weld pool metal in this case.

The change in the dimensions of the $\gamma^{\prime}$-phase over the weld section is less noticeable and is within the measurement error. The effect of the welding speed on the size of the $\gamma^{\prime}$-phase is manifested only in the transition from low to high speeds (Fig. 11). So, if in the welds made at a welding speed of $12 \mathrm{~m} / \mathrm{h}$ - the diameter of $\gamma^{\prime}$-phase particles in the axes of the dendrites is $\sim 60-80 \mathrm{~nm}$, in the interdendritic regions $100-$ $110 \mathrm{~nm}$, then at a welding speed of $\sim 60-90 \mathrm{~m} / \mathrm{h}$, respectively-3050 and $50-70 \mathrm{~nm}$.

\section{DISCUSSION}

Consideration of the peculiarities of the structure of welded joints of heat-resistant nickel alloys single crystals is explained mainly by the inhomogeneity of the temperature-temporal and temperature-spatial fields caused by welding, the nonequilibrium processes of heating, melting, crystallization and cooling. In addition, the observed difference in the sizes and morphology of the $\gamma^{\prime}$-phase and dendrites over the cross-section of the welded joint, as well as their dependence on the welding speed, is associated with the fact that the formation of the dendritic structure of the $\gamma$-solid solution occurs during the crystallization of the weld pool melt with different degrees of overheating, and the formation of the $\gamma^{\prime}$-phase during cooling of the $\gamma$-solid solution of the crystallized weld metal or heat-affected zone at lower $\left(T_{\mathrm{s}}-T_{\text {c.d. }}\right)$ temperatures and at different rates.

There is a tendency not only to minimize the size of the structural components of heat-resistant nickel alloys single crystals during welding, but also to change their morphology, including carbide precipitates. This is especially noticeable at the welded joints obtained at speeds of $40-50 \mathrm{~m} / \mathrm{h}$. Carbide discharges are reduced: acicular to a length of 1-2 microns, globular to a diameter of 100-500 nm. Carbides in the weld are edged with dendrites. This tendency can be explained by the value and nature of heat input into the weld pool, when the maximum temperature gradient, the rate of solidification and cooling of the weld metal are provided [19].

The results of the performed metallographic studies of the structural features of welded joints of heat-resistant nickel alloys single crystals, as well as the interpretation of the mechanism of its formation, are in good agreement with the previously performed studies of the temperature-time and temperature-spatial characteristics of the welding process $[19,20]$, the established dependences of the rate of solidification and cooling of the weld metal on the welding speed, changes in the value of the crystallization parameters $G$ and $R$ over the weld cross 


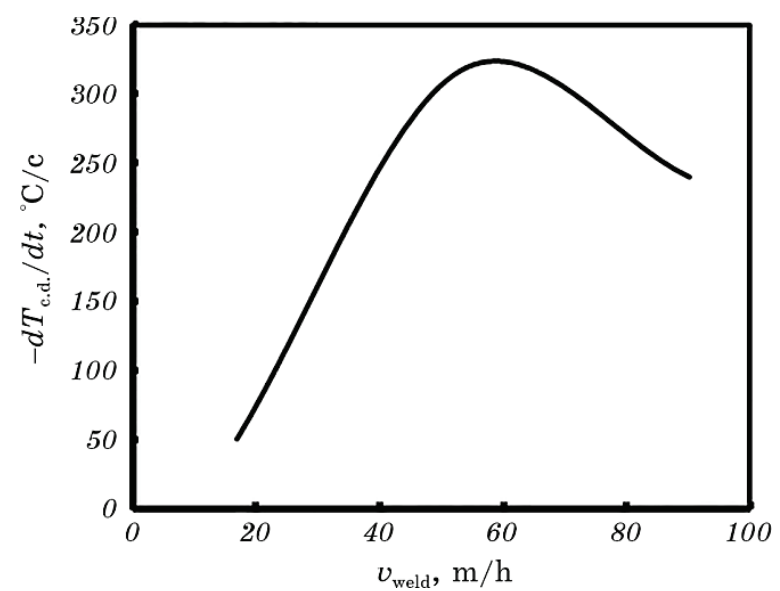

Fig. 10. Dependence of the rate of cooling of the weld metal $(d T / d t)$ of the ZhS26 alloy on the welding speed $\left(v_{\mathrm{w}}\right)$ in the temperature range of the $\gamma^{\prime}$-phase formation.

section at different welding regime [19].

The possibilities of controlling the quality and structure of a welded joint by technological means by choosing a scheme and welding regime are shown. Some variants of obtaining a certain dispersion of the main hardening phase of the heat-resistant nickel alloys $\gamma^{\prime}$ can be concluded, for example, from the analysis of the generalized dependencies shown

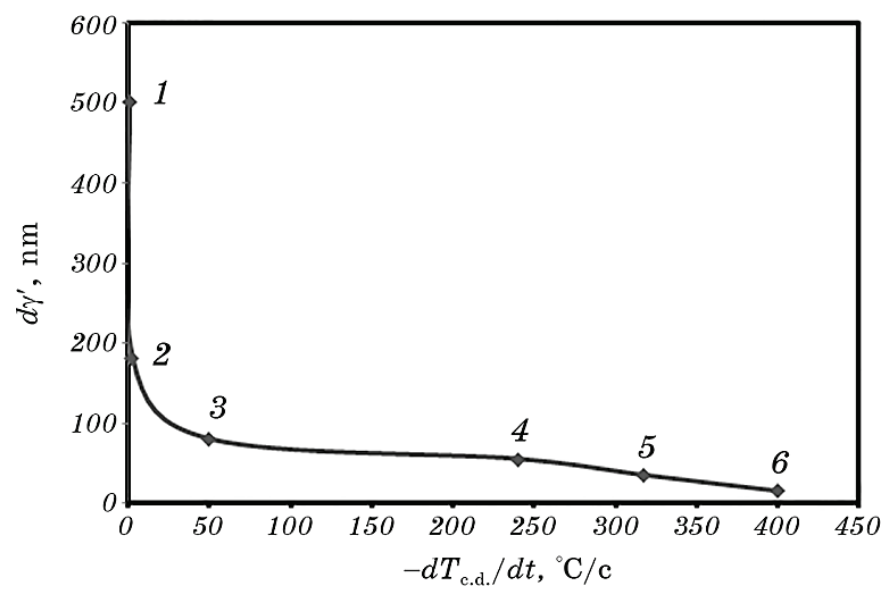

Fig. 11. Dependence of the size of the precipitates of the $\gamma^{\prime}$-phase $\left(d_{\gamma^{\prime}}\right)$ on the cooling rate $(d T / d t)$ of the metal in the temperature range of the formation of the $\gamma^{\prime}$-phase: 1 -base metal $\mathrm{ZhS} 26,0.5^{\circ} \mathrm{C} / \mathrm{s} ; 2$-base metal $\mathrm{ZhS} 32,3^{\circ} \mathrm{C} / \mathrm{s} ; 3$ ZhS26, $v_{\mathrm{w}}=12 \mathrm{~m} / \mathrm{h} ; 4-\mathrm{ZhS} 26, v_{\mathrm{w}}=90 \mathrm{~m} / \mathrm{h}, 5-\mathrm{ZhS} 26, v_{\mathrm{w}}=53 \mathrm{~m} / \mathrm{h} ; 6-$ ZhS36, $v_{\mathrm{w}}=53 \mathrm{~m} / \mathrm{h}$. 
in Figs. 10, 11.

From the obtained research results, it follows that welded joints of heat-resistant nickel alloys single crystals should be considered as a composition consisting of different sections differing in structure, phase and chemical composition.

The considered structural features of both individual elements of this composite and their combination will determine the mechanical and service properties, crack resistance, and other characteristics of a single-crystal welded structure.

Currently, we are working on detailing such dependencies and developing methods for improving the quality of the structure of welded structures made of heat-resistant nickel alloys single crystals in terms of ensuring the regular location of the strengthening $\gamma^{\prime}$-phase, optimizing their size and morphology.

\section{CONCLUSION}

1. Welded joint of heat-resistant nickel alloys single crystals made by EBW is a composition of different-structured areas differing in size, morphology, type, chemical composition of the main structural components-dendrites, $\gamma-\gamma^{\prime}$-phases, eutectic formations, carbides.

2 . The features of the structural components of welded joints are determined by the significantly higher $G$ and $R$ values and the value of their ratio compared to the growth of single crystals, the irregular distribution of temperature fields, high heat input concentration and other parameters associated with the energy characteristics of electron beam welding.

3. The main features of the structure of welded joints of heat-resistant nickel alloys single crystals are smaller in comparison with the base metal, dendrites varying over the weld cross section; nano-sized precipitates of the $\gamma^{\prime}$-phase of different dispersion in the heat-affected zone and weld metal, less chemical heterogeneity.

4 . The sizes of separate zones of the welded joint, the degree of dispersion of the structural components, the chemical heterogeneity of the weld metal are largely determined by the main technological variable of the process - the welding speed, as well as the value of the thermophysical characteristics of the welded alloy $\left(T_{\mathrm{L}}, T_{\mathrm{S}}, T_{\mathrm{s}}-T_{\text {c.d. }}\right)$.

5 . When developing welding technology for construction made of heatresistant nickel alloys single crystals to provide the uniform distribution over the cross section of the welded joint and in the $\gamma$-matrix, optimize the dimensions and morphology of the main hardening $\gamma^{\prime}$-phase, it is necessary in each case to adjust the regime and scheme of welding, as well as heat treatment with taking into account the features of the structure obtained as a result of welding. 


\section{REFERENCES}

1. R. E. Shalin, I. I. Svetlov, E. B. Kachanov, V. N. Tolorayya, and O. S. Gavrilov, Monokristally Nikelevykh Zharoprochnykh Splavov [Single Crystals of Nickel Heat-Resistant Alloys] (Moscow: Mashinostroenie: 1997) (in Russian).

2. H. Hurada, Proc. of 'International Gas Turbine Congress-2003' (November 2-7, 2003) (Tokyo: 2003), p. 1.

3. $\quad$ E. N. Kablov, N. V. Petrushin, and E. S. Elyutin, Vestnik MGTU im. N. E. Baumana. Ser. 'Mashinostroenie', SP2: 38 (2011) (in Russian).

4. G. B. Stroganov and V. M. Chepkin, Liteynye Zharoprochnye Splavy dlya Gazovykh Turbin [The Casting Superalloys for Gas Turbine] (Moscow: ONTI MATI: 2000) (in Russian).

5. E. N. Kablov, N. V. Petrushin, I. L. Svetlov, and I. M. Demonis, Aviatsionnye Materialy i Tekhnologii, No. 5: 36 (2012) (in Russian).

6. Chester T. Sims, Norman S. Stoloff, and William C. Hagel, Superalloys II: High-Temperature Materials for Aerospace and Industrial Power (New York: John Wiley Sons Inc.: 1987).

7. Litye Lopatki Gazoturbinnykh Dvigateley (Supersplavy, Tekhnologii, Pokrytiya) [Cast Blades of Gas Turbine Engines (Superalloys, Technologies, Coatings] (Ed. E. N. Kablov) (Moscow: Nauka: 2006) (in Russian).

8. E. N. Kablov, Yu. A. Bondarenko, A. B. Echin, V. A. Surova, and D. E. Kablov, Vestnik MGTU im. N. E. Baumana.Ser. 'Mashinostroenie’, SP2: 20 (2011) (in Russian).

9. A. B. Echin and Yu. A. Bondarenko, Aviatsionnye Materialy i Tekhnologii, No. 4: 14 (2014) (in Russian).

10. T. M. Pollock and W. H. Murphy, Metall. Mater. Trans. A, 27A: 1081 (1996).

11. J.-W. Park, S. S. Baby, J. M. Vitek, E. A. Keni, and S. A. David, J.Appl.Phys., 94, No. 6: 4203 (2003).

12. K. A. Yushchenko, B. A. Zaderiy, I. S. Gakh, A. V. Zvyagintseva, and O. P. Karasevskaya, Metallofiz. Noveishie Tekhnol., 35, No. 10: 1347 (2013) (in Russian).

13. K. A. Yushchenko, B. A. Zaderiy, I. S. Gakh, A. V. Zvyagintseva, and O. P. Karasevskaya, Metallofiz. Noveishie Tekhnol., 31, No. 4: 473 (2009) (in Russian).

14. K. A. Yushchenko, B. A. Zaderiy, A. V. Zvyagintseva, S. S. Kotenko, E. P. Polishchuk, V. S. Savchenko, I. S. Gakh, and O. P. Karasevskaya, Paton Welding J., No. 2: 6 (2008).

15. K. A. Yushchenko, B. A. Zaderiy, I. S. Gakh, A. V. Zvyagintseva, and O. P. Karasevskaya, Fizicheskie i Tekhnicheskie Problemy Sovremennogo Materialovedeniya [Physical and Technical Problems of Modern Materials Science] (Kyiv: Akademkniga: 2013), vol. 1, p. 148 (in Russian).

16. K. A. Yushchenko, I. S. Gakh, B. A. Zaderiy, A. V. Zvyagintseva, and O. P. Karasevskaya, Paton Welding J., No. 5: 45 (2013).

17. M. A. Krivoglaz, Difraktsiya Rentgenovskikh Luchey i Neytronov $v$ Neideal'nykh Kristallakh [X-Ray and Neutron Diffraction in Nonideal Crystals] (Kyiv: Naukova Dumka: 1983) (in Russian).

18. O. P. Karasevskaya, Metallofiz. Noveishie Tekhnol., 21, No. 8 : 34 (1999) (in Russian).

19. K. A. Yushchenko, B. A. Zaderiy, I. S. Gakh, and O. P. Karasevskaya, 
Paton Welding J., No. 8: 15 (2016).

20. K. A. Yushchenko, B. A. Zaderiy, I. S. Gakh, and A. V. Zvyagintseva, Paton Welding J., Nos. 11-12: 83 (2018). 